\title{
Dobrawa Lisak-Gębala*
}

University of Wrocław

\section{CONTEMPORARY POLISH ESSAYS: IN SEARCH OF THE AURA OF PAINTINGS AND PHOTOGRAPHS ${ }^{1}$}

\begin{abstract}
When an essay, as a specific form of writing, is conventionally compared to travel, the latter is understood not only as a model of translocation but also as a literary genre. The parallel between essays and travel writings identifies their numerous common elements in text, for instance a movement between the topics, the observer's visible distance, an intellectual journey (the last term was introduced by Walter Pater in his pioneer reflections on the essay in 1893). The listed similarities encourage the writer of this article to formulate a rudimentary statement: both real and literary travel and the act of writing an essay are usually undertaken to discover a thing worth one's attention and interest; a thing that, even if commonly known, should be, firstly, experienced, and secondly, depicted in a way that would cast new light on it.
\end{abstract}

Key words: literary genre, essay, act of writing, experience, real and literary travel

Theodor W. Adorno in his work entitled The Essay as Form describes the specific happiness of unconstrained essayistic exploration: "the object of essay is the new as something genuinely new, as something not translatable back into the staleness of already existing forms", and later adds, that essay "becomes a compelling construction that does not want to copy the object, but to reconstruct it out of its conceptual membra disjecta" (Adorno 1984: 169). As a consequence, in a model form of a travel essay (which is

* Institute of Polish Philology, Univeristy of Wroclaw, Plac Nankiera 15, 50-140 Wroclaw, e-mail: dobrawa_lisak@o2.pl

1 The project was financed by NCN and contributed under the number DEC-2011/01/N/ HS2/00510. 
a distinctive subgenre of essay writings) the described search of novelty should be certainly taken into account. Supposedly, what seems the most attractive for authors of travel essays are the excursions to unknown regions intriguingly labelled "ubi leones". Experiment, risk, originality, individual experience - all those elements are repeated in various preliminary definitions of an unstable, protean essayistic form (e.g. Bense 2012, Atkins 2005, Sendyka 2006).

Considering contemporary Polish travel essays, an important question might be asked: how to discover this individual voice and the novelty of the essay's object when the traditional place of an artistic pilgrimage comes to be the destination of a real journey, described subsequently in the text. The great amount of eminent Polish travel essays (Zbigniew Herbert's Barbarzyńca w ogrodzie [Barbarian in the Garden], Jarosław Iwaszkiewicz's Podróże do Włoch [Travels to Italy], Wojciech Karpiński's Pamięć Włoch [The Memory of Italy] and Ewa Bieńkowska's Co mówia kamienie Wenecji [What Do the Stones of Venice Say]) treat Italy - a land described by innumerable writers (Goethe, Byron, Madame de Staël, Stendhal, Chautebriand and John Ruskin among the others); a land full of works of art that are inevitably perceived not only by essayist-erudite's own eyes, but also through the prism of some famous authors' accounts ${ }^{2}$. Apparently one could believe that there is nothing new to find in this country. Wojciech Karpiński in the 1982 credo of his Italian pilgrimage, resists such a melancholic feeling of surfeit which he compares to blindness, a paralysis of sensitivity, and suggests that the kind of journey he describes is the best treatment for acedia, a way to reintegrate one's personality and to refresh one's insight (Karpiński 2008: 17). The redundancy of external stimuli, of remembered descriptions and cultural associations does not necessarily have to be treated as a burden, especially when the feeling of connectedness with the European tradition is strong and when the project of penetrating the visited place and its art is based on an individual plan of interpretation followed by the construction of the essay. It becomes evident why Adam Szczuciński claims that writing about Italy becomes "making notes on the margins of the others' works" ("pisanie o Włoszech [...] jest [...] zapiskami na marginesach cudzych dzieł" - Szczuciński 2008: 61).

2 In case of other notable travel essays by Herbert (Martwa natura z wędzidłem [Sill Nature with a Bridle]) and Karpiński (Amerykańskie cienie [American Shadows], W Central Parku [In the Central Park]), although those texts present different areas and not Italy again, it can be claimed that they are equally supported by library readings and visits to the museums. 
But the same intertextual origins can be found in case of Montaigne's Essays: the work that, in the 20th century reflection on essay, has become an archetype of a typically modern inscription of an individual, processual experience (e.g. de Obaldia 1995: 37-38; Lopate 1994: XLIV). As Phillip Lopate argues, although "the whole modern essay tradition sprang from quotation" (Lopate 2012: 131), nowadays the most influential position in essay writing is not preoccupied by common literary culture but by personal experience and an individual voice. This diagnosis, transplanted to the context of Polish travel essays on paintings, expresses the need to underline an individual way of experiencing the work of art, revealed indirectly in numerous ekphrases and often defined explicite in autothematic commentaries describing the circumstances of looking at pictures, the events preceding and following the moment of admiring these paintings. Analysing those components, we can build specific, individual maps of chosen essayists' intellectual journeys.

Nevertheless, many well-read writers seem to be completely unable to travel alone, as numerous records of this culturally recognized Grand Tour to Italy, created by authors representing various countries and periods, are indeed very often mentioned and quoted in the above-mentioned Polish travel essays. However, the abundant repertoire of others' interpretations is usually treated as a preparatory course, rather than as an obstacle. A cultural background seems to be necessary for the beginners before their actual visit to Italy, because other travellers' writings can even teach diligent novices how to find their singular mode of art's experience. As an illustration, Iwaszkiewicz and Karpiński openly establish an imagined conversational community of travellers admiring the same works of art in different times and circumstances, and, at the same time, these two authors underline their individual experience of those pictures. Iwaszkiewicz, after listing famous artists (Eugène Delacroix, Jan Matejko, Stanisław Wyspiański, Zygmunt Krasiński and Cyprian Norwid) who, just like him, viewed the Venetian Assunta by Tiziano notes: "And each one of us saw his own Assunta", and then, starting a discreet game with an epiphanic model of art's reception, adds: "Should I say: his own Assumption?" ("A każdy z nas widziat swoja Assuntę. Czy mam powiedzieć: «swoje wniebowzięcie»?" - Iwaszkiewicz 2008: 14). Karpiński in turn, while reporting his contact with Signorelli's frescos in Orvieto, admits his lasting memory of other authors' interpretations stratifying on the surface of image and shows advantages of the unsolitary experience of art. After mentioning Iwaszkiewicz, Miłosz, Herbert (three Polish writers which were older than him), he notes: "When I stood in front of Signorelli I remembered 
about those meetings. Not only did they not disturb me, but they helped me see the work on my own" ("Gdy statem przed Signorellim, pamiętatem o tamtych spotkaniach. Nie tylko nie przeszkadzały mi patrzeć, lecz pomagały w zobaczeniu dzieła na własna rękę" - Karpiński 2013: 130-131). This replication of delight in art, on the one hand confirms the essayist's participation in the European cultural tradition and in the community of persons that, due to their sensibility and connoisseurship, are able to appreciate works really worth one's attention (and not necessarily the most famous ones). On the other hand - such a repetition of delight would not be of much importance if it did not contain also the unpreceded trait of individual experience ("to see on my own").

Contemporary Polish essays on paintings present diverse types of image reception. For example, a reception can be focused on formal, artistic features, or concentrated around developing some extravisual associations by either considering the original context or the picture's resemblance to today's reality. In this article, I would like to distinguish another important type of reception which is an essential element of travel essays on paintings: the one based on the viewer's experience of a picture's aura. Such an experience allows us to observe some significant convergences of the reception of art with the model form of an essay and idea of travel accounts, as has been mentioned in the initial part of this inquiry. The auratic experience is linked to the notion of an experiment and risk. Additionally, in the field of this interesting type of reception the object, even one veiled with a web of citations, should be still able to show its novelty. The term "aura", introduced by Walter Benjamin, is understood as the distinctiveness of the work of art, based on its uniqueness and originating from a particular place and time. According to the philosopher's description, aura is "a strange weave of space and time; the unique appearance or semblance of distance, no matter how close it may be" (Benjamin1998: 518). It becomes evident why searching for the aura could be easily connected with two important strategies of overcoming the cultural and historical distance which are distinctive of Polish travel essayists. Those strategies are: actual journeys to historical sites and imaginary time travels. Moreover, the experience of a painting's aura reveals the writer's personal voice and often results in an emotional and artful ekphrasis. Such a subjective description about an especially attractive picture works as a mirror for the essayistic "self", as a medium of self-cognition and self-presentation (Sendyka 2009).

An attempt at creating one's virtual collection - a specialized gathering of auratic images, individual impressions and quotes from the writings of 
predecessors - often becomes a preferred starting point for inventing a refreshed essayistic insight and singular mode of experience. According to Karpiński's suggestion, the full experience of Italy "requires a delicate balance between ignorance and pedantry, between distraction and speculation" („,wymaga delikatnego wyważenia między ignorancja a pedanteria, między nieuwaga a spekulacja" - Karpiński 2008: 70). This balancing "in-between" resembles the typical situation of essayist who is a writer that chooses a form characterised by tension between art and science, between subjectivity and objectivity, between freedom and discipline (Atkins 2005: 112). Adorno claims that an essayist should be a dilettante and amateur suspending his erudition. Moreover, an essayist's choice of both the beginning and the end of his exposition should be made wilfully with "childlike freedom" (Adorno 1984: 152). Since Montaigne's essay seems to be a form which opposes the narrow ideals of a dogmatic system, a predictable order or completeness, it is clear why this form of writing is often presented as antiscientific. The essay's "in-betweeness" appears to be a kind of an "unmethodical method" (Atkins 2005: 114). Analysed travel essays prove this hypothesis because, while their authors make supposedly spontaneous choices, meanwhile, they reveal certain purposeful attitudes: essayists' searching for the aura indeed give the impression of a kind of an "unmethodical method", it is both deliberate and random, both carefully arranged and free spirited. It is rooted in a strictly specified cultural and historical area but dependent on some changing circumstances.

In order to experience the aura, the mentioned essayists concentrate mainly on bringing an imaginary revival of lost time and place, of a certain point from the past from where the work of art originates. Herbert quotes "Goethe's wise dictum: Wer den Dichter will verstehen, muss in Dichters Lande gehen" and openly declares: "As the fruits of light, paintings should be viewed under the artist's native sun. Sasseta seems out of place even in the most attractive American museums. Hence the pilgrimage to Piero della Francesca" (Herbert 1985: 149). It can be that claimed the author of Barbarian in the Garden travels to Italy in order to find the experience of aura, and many other essayists act likewise. Karpiński intends to see Italian towns and cities through the prism of great amount of various historical sources combined altogether: he includes paintings, the pieces of knowledge about particular past events, biographies, architecture, literary texts, politicians' treatises and the way of exercising the power. Ewa Bieńkowska similarly develops her project of "historical anamnesis", which means an attempt at rediscovering the history of collective imagination of the Venetians from cinquecento, seicento and settecento, the metamorphoses 
of their spirituality hidden in the paintings. A description of an auratic experience of art can also appear in the essay in a less methodical form, rather capriciously, without previous announcement. This is the case with Jarosław Iwaszkiewicz's summa vitae - Travels to Italy. In the introductory commentary the writer underlines his will of distinguishing himself from other travellers thanks to the autobiographical impulse which binds the texture of his essay. As a consequence, Travels to Italy turn out to be a mosaic self-portrait of the artist. Due to this almost egotist perspective some random and unpredictable circumstances appear as the necessary conditions of an auratic experience of some chosen pictures. Not only intersubjectively available details, like the historical character of a place where a picture is exposed or the advantages of a work itself, seem to be an adequate ground for the bloom of aura. Such an unusual experience, according to Iwaszkiewicz, also requires an appropriate viewer's mood, it depends on his recent sensations and even on the weather. Hence the revelation of aura, although sought in the Italian cultural treasuries, does not have to be fulfilled.

An important problem is that in $20^{\text {th }}$ and $21^{\text {st }}$ essayistic travel records we can find numerous fragments which describe the progressive vanishing of aura and enlist some obstacles that hinder the full contact with Italy treated as the artistic zone. Those commonly denigrated interruptions are connected with some seemingly extraneous details and civilizational forms: the institution of museum and practices of art exposing, mass tourism, the modernisation of city areas, which may collectively be recognized as the signs of all changes found in the valuable historical space that the essayist would still love to see as an untouched preserve of ancient Italy's aura, just like it probably appeared in the times of Goethe or Stendhal.

According to all discussed essayists, in the case of paintings originally housed in churches moving them to art galleries becomes a main reason of an irreversible loss of aura. Iwaszkiewicz, who visited Italy many times since 1924, could observe and judge many such changes. He argues, for example, that the famous fresco Triumph of Death from Palermo was received in an absolutely different manner in its natural surroundings of monastery walls than in the museum where "cleaned and isolated counts only on immediate visual effect" (oczyszczony $i$ odosobniony, obliczony jest juz tylko na bezpośrednie działanie malarskie - Iwaszkiewicz 2008: 10). This conclusion illustrates how practically Malraux's idea of le musée imaginaire is realised: the "religion of art" replaces the traditional cult; in the "imaginary museum" items originating from different traditions are equalized as the objects meant to make impression only thanks to their sensual impact (Mal- 
raux 1967). No wonder that Herbert complains: "The rapid swallowing of paintings (in large doses) is as pointless as the swallowing of kilometres" (Herbert 1985: 73), while in the gallery full of equally treated exhibits viewers are forced to face the overwhelming surplus of stimuli. Iwaszkiewicz describes the Venetian Galleria dei Belle Arti as a "storehouse of needless pieces of junk" ("skład niepotrzebnych rupieci") and states bitterly: "Our museums are not Epicur's gardens" ("Nasze muzea nie sa ogrodami Epikura" Iwaszkiewicz 2008: 31). In the opinion of this author, museums do not offer a background for cultural cruciate, neither guarantee the refuge for the values of European culture. As Katarzyna Szalewska argues, an institutional gallery is valued ambivalently by Polish travel essayists; on the one hand, according to Herbert, Bieńkowska and Karpiński, a museum provides an opportunity for individual contact with art that integrates the "self"; on the other hand, a museum is often perceived as an empty storage of lifeless history (Szalewska 2012: 316). As a result, the supposed pilgrimage often turns into a tedious effort of passing numerous rooms which is hardly salvaged by the minor prize of discovering some fascinating experience. While the structure of the museum reproduces some demarcations, typologies introduced by art historians ("scholarly insects" as Herbert calls them), such critical diagnosis of institutionalised galleries is linked clearly with antiscientific attitudes of essayists. For instance, Bieńkowska claims that an encounter with art at the museum is a situation rather intellectual than experiential - annihilating the chance of any imaginary restoring scenes from paintings back to life, expunging any illusionistic interpretations of picture (Bieńkowska 2002: 247). Essayists' very selective collecting of especially attractive paintings could be observed at the level of their texts' composition. Probably during actual museum visits those authors also choose only few adorable works to join their "imaginary collection". This selectiveness of essayists' preferences seems to be an advantageous strategy of dealing with the structure of huge galleries, because such a critical attitude, linked with ignorance of the majority of exposition, enables the chance to catch several revelations of aura.

Ewa Bieńkowska presents herself as a very sensitive viewer. Her criticism embraces not only the institution of a museum, but also some exhibitory practices met in old Italian churches, places by their nature predestined to be auratic. The authoress of What Do the Stones of Venice Say notices many civilizational changes diminishing the historical character of sacred interiors. Bieńkowska, as a writer fixed on the mysticism of light, underlines the unsuitable impact of electricity, called by her "an abstractive nakedness" ("abstrakcyjne obnażenie" - Bieńkowska 2002: 181), and presented 
as distant from twinkling candle flames which seem full of life. It reminds us of Iwaszkiewicz complaints on the exhibition of Giorgione's masterpiece (he found The Storm guarded by heavy glass which hindered any perception of painting) or on the technique of renovation that transforms precious pictures - ancient and auratic in their deterioration - into loudly coloured, glittering objects which had already lost all features caused by their age. According to the two above-mentioned essayists, such achievements of civilisation as the stable, homogenous light, glass protecting the masterpiece or modern techniques of renovation may effectively annihilate aura, although those innovations were arranged either to keep the works safe or to facilitate the perception of art.

Another important thematic area is connected with the contemporary shape of historical sites. Essayists writing about their Italian tours often endeavour to extend the successfully discovered aura towards the scenery of cities and their surroundings, since these authors describe panoramas in a highly painterly way, similar to depictions of old artworks. A figure transforming distinguished views into potential pictures could be called an "imaginary ekphrasis" (John Hollander's term: Hollander 1998). However, the modernisation of urban spaces again turns out to be a main obstacle on the way to recognize alleged prototypes of landscapes known from famous paintings or at least of some that resemble artful Italian pictures. Iwaszkiewicz seems to be a tireless seeker of the latest civilizational modifications, plenty of which are discredited by him as bringing dissonance in the experience of a traveller searching for the anterior aura. New styleless buildings, traffic and the crowd are usually listed in analysed essays as disadvantages of $20^{\text {th }}$ century urban life. Whereas such complaints, especially about cars, could be also found in publications from two initial decades of 20th century: in Paul Muratow's travel writings often quoted by Polish essayists (in addition: since the Polish translation in $1969 \mathrm{Mu}-$ ratow's texts established in Poland a certain paradigm of the genre), this criticism might be treated as a recurrent topoi of such essays. Moreover, the myth of 19th century Italy as an uncontaminated preserve of aura shaped by famous romantic travellers still seems to be a point of reference. The phenomenon that could not have been observed by Muratow is mass tourism which history dates from circa 1925. In Iwaszkiewicz's Travels Americans sitting in the squares of Rome are treated with some dose of friendly tolerance and called "hippies", although sometimes they are given some features similar to Rousseau's "good savage". This author notices also with a bit of satisfaction the presence of Japanese tourists. Herbert instead is less forbearing: 
Loud guides drive herds of tourists. Sweating farmers from a distant country film every piece of wall which the guide shows them and obediently manifest enthusiasm by touching ancient stones. They are so absorbed with producing copies that they have absolutely no time to see. They will visit Italy at home: colourful moving pictures that have nothing to do with reality. No one has any desire to study things as they are. A tireless mechanical eye multiplies emotions as thin as film. (Herbert 1985: 68-69)

This kind of pointing out the incompetence of a passive consumer might be inscribed in the wider frame of criticism towards mass culture (Shallcross 2002: 47). As many commentators claim, this disapproving attitude is typical for contemporary essays as niche and exclusive forms proudly opposing the "private, idiosyncratic voice" to omnipresent "anonymous babble" (Sanders 2012: 124).

After enlisting diverse difficulties met in the alleged sanctuaries of aura it is vital to present some positive strategies of contemporary Polish travellers to Italy, some alternative procedures that overcome melancholic mourning of this land's historical atmosphere seen as lost forever and unavailable. Those projects usually resemble the advice from a tourist guidebook, but interpreted a rebours, beginning with reversing recommended places and seasons. As an illustration, Iwaszkiewicz admits that he usually travels in November, during the month when tourists are almost absent in Italy. The act of detecting some asylums and artworks abandoned by mainstream functions as a source of great delight as well. Herbert, having left the main touristic routes, rediscovers the aura of a less known masterpiece by Piero della Francesa - Madonna dell Parto - housed in a little chapel in Monterchi (Herbert 1985: 153-154), while Iwaszkiewicz, during his visit to the Venetian Basilica of San Marco, ignores the splendid interior and concentrates on the small side chapel of San Isidore, because it reminds him of the intimate atmosphere of Polish village churches (Iwaszkiewicz 2008: 22). Also Bieńkowska and Marek Zagańczyk (a travel essayist from the younger generation) often describe their magnificent discoveries hidden in out-of-the-way places that are usually closed and not meant for tourists. For example, Zagańczyk admires a picture found in some "stuffed sacristy" (Zagańczyk 2005: 39).

All observed circumstances connected both with a textual and extratextual world incline the writer of this article to ask whether there could be found some traces of exhaustion in the seemingly institutionalised discourse of Italian artistic travels; such a hypertrophy of others' commentaries and of civilizational obstacles that make the full, immediate experience of paintings more and more difficult. In other words, is it true that while intending 
an affirmative description of a famous Italian picture and its surroundings it is increasingly troublesome not to write about some banal commonplaces, or not to develop some bitter critique? Certainly, the answer cannot constitute an authorized thesis, especially when referred to the future, but it is still worth to search for it because, considering the two more recent pieces of essay writing about visits to Italy (Adam Szczuciński's Włoskie miniatury [Italian Miniatures] and Marek Zagańczyk's Droga do Sieny [The Track to Siena]), an important transformation of travel discourse becomes evident. Although in these texts Italy still seems to be a land permeated by art and is treated as a preserved sanctuary of the past, the directly declared aim of the excursion is no longer to see and admire art in itself or to gain the auratic and individual experience. In this sense, the two above-mentioned younger authors seem to continue the sneakiness of Iwaszkiewicz's statement formulated almost 50 years earlier: "Travelling in order to watch flowers is as good as travelling in order to watch the architecture or paintings" (Podróżowanie po Włoszech "po kwiatach» jest równie dobre jak każde inne, «po architekturze»czy «po obrazach»- Iwaszkiewicz 2008: 12). As this writer claims, when someone stubbornly intends to create another (usually boring) description of an Italian tour, speaking on any other subject would be the best thing to do. But Szczuciński and Zagańczyk are much more consistent than Iwaszkiewicz. Zagańczyk tries to apply an alternative perspective by looking through the "other's eyes" (Zagańczyk 2005: 8), while searching for his idée fixe - the beloved view of a valley, an adorable hybrid of combined landscapes remembered from paintings or imagined when reading famous travel accounts. Szczuciński is looking for some trails of eminent writers that visited Italy, for instance, he presents Josif Brodsky's travel to Venice. The intertextuality is a typical feature of this kind of essay writing (or even of essays at all) but in the case of these two authors it is exceedingly intensified. It can be demonstrated by the fact that, for example, in a part of an essay that is usually dedicated to presenting highly subjective descriptions of paintings, accounts that express the essayist's personal voice, in Zagańczyk's book the reader finds some quotations of the other authors' ekphrases. The usual "seeing on my own" essay strategy (mentioned by Karpiński, and practiced by Herbert, Bieńkowska, Iwaszkiewicz and many others) is replaced by "seeing through the other's eyes". Consequently, the one of fundamental ideas of travel writing, in which the accounts should be based on one's search for unconstrained individual experience of art, is clearly absent in the latest Polish essays mentioned in this paragraph.

During the last decade, next to the slightly transformed model of Italian tour distinctive of Zagańczyk and Szczuciński's books, another im- 
portant tendency could be observed in the field of Polish essayistic travel writing, while there has been established an alternative route towards the South of Europe. The latter phenomenon does not concern the journey undertaken by a man from the North going South in order to pass the cultural initiation or to regain his creative powers. This route is directed rather towards the East. The most representative literary examples are Andrzej Stasiuk's books (Jadac do Babadag [Going to Babadag] and Dziennik pisany później [Diary Written Afterwards]); essayistic records from the excursion in search of the mythic Central Europe, grounded in the archaic past. The institutionalisation of two distinguished oppositional types of discourse could be easily observed. "Zeszyty Literackie" in the series called "Travels", edited by Marek Zagańczyk, publishes traditionally oriented cultural and artistic travel writings (the new original pieces, but also some re-editions or translations, including the classic realisation of Italian travels - Muratow's Images of Italy). "Czarne" owned by Stasiuk has its travel series too. It is called "Sulina" and presents the accounts of unusual journeys through forgotten corners of Europe. An essential feature of Stasiuk's essay is a very specific identity of the "self": it is far from both the ideal citizen of Europe and from "barbarian in the garden" defined by Herbert as a traveller from a poor, isolated country, but who aspires to join the great European society with its high culture. For Stasiuk the Mediterranean tradition and masterpieces of art definitely are not a positive point of reference. He identifies himself with the inhabitants of Central Europe; he declares his allegiance to Ukrainians and people from Balkan countries. His myth of a Central European identity (and Polish identity as well) is formed by the category of the "outcasts of the West, traitors of the East" ("wyrzutki Zachodu, zdrajcy Wschodu” - Stasiuk 2011: 160). Travelling through Central Europe locations, he trails not only the atmosphere of the past but also intends to feel the authenticity of life or even some horror.

The comparison of the traditionally arranged travels to Italy with Stasiuk's excursion to the unknown regions of Central Europe might be interesting and seemingly it is not ungrounded, while the project of Stasiuk' travelling was thoroughly criticized by Marek Zagańczyk, one of the advocates and admirers of Mediterranean heritage:

Świat Stasiuka kończy się tam, gdzie mój zaczyna, i jest odległy od tego, co sam dla siebie wybrałem (...). Nie ma u Stasiuka miejsc rzeźbionych wspólną pamięcią. Nie ma tak ważnego dla mnie splotu natury i kultury. Jest to zapis rozpadu, obraz świata w zaniku. Gubię się wśród nazw węgierskich, albańskich, rumuńskich. Żadna mapa mi nie pomoże (Zagańczyk 2005: 77). 
Stasiuk's world ends where mine begins and it is far from what I have chosen for myself $[\ldots]$. There are no sites sculpt by collective memory. There is no entanglement of nature and culture which has been of such importance for me. It is a record of destruction, a picture of vanishing world. I feel lost amongst Hungarian, Albanian and Romanian names. No map can help me. [translation by the author of the article]

Notwithstanding this antagonism, although the two types of travel essays present themselves as alternatives, it is possible to point out some features shared by both projects. These common elements are: the distance to globalization and mass culture, diving into the past, searching for some inspiring experience, and the mighty desire for freedom (also because of leaving Poland). Summing up, those elements could be described as a specific kind of escapism, often demonstrated in one's longing for the preserved mythic past, the search of which is an act based on many idiosyncratic choices. And maybe this escapism has something to do with the essayistic form itself since Carl H. Claus concludes: "So it might be said that above all else essayists conceive of the essay as a place of intellectual refuge, a domain sacred to the freedom of mind itself" (Claus 2012: XXI). In travel essays the free movement of thoughts is accompanied by an actual translocation and escaping from todays' reality, so it is a multiplied refuge.

The above hypothesis constitutes an adequate background for interpretation of another pair of essayistic books published by "Czarne" - Wojciech Nowicki's Dno oka (Fundus of the Eye from 2010) dealing with the subject of old photographs and Salki (The Attics - published in 2013) where an excursion similar to the one undertaken by Stasiuk is depicted: including an analogous destination (Ukraine and Balkan countries) and the search for intriguing otherness. In Nowicki's texts the act of translocation is apparently connected with time travelling, realised in two forms: as telling a story about old photographs and people presented in those pictures (in Dno oka), and also as looking for places where time has seemingly stopped (in Salki). Additionally, this convergence of travelling and an interest towards old photographs is present in Going to Babadag as well. Stasiuk claims that his plan of travelling and writing a book was born due to his former enthusiasm for Andre Kertesz's work presenting a blind violinist: "Wherever I go I search for its [photograph's] three-dimensional, coloured versions and I often feel that I find them" (Dokąd się nie wybiorę, szukam jego [zdjęcia] trójwymiarowych $i$ barwnych wersji, i często wydaje mi się, że je znajduje - Stasiuk 2004: 210).

When two books by Nowicki are treated as complementary texts, it is vital to say that they contain several basic elements that turned out to be essential for the construction of classical essays about Italy mentioned in 
the initial part of this article. The common features of all these essays are: the narrative frame of a travel, reference to visual arts and the most important one - searching for asylums of auratic experience. Nowicki presents himself as a seeker of "gatherings from the borderland of a circus, science and pornography" (zainteresowanie zbiorami na pograniczu cyrku, nauki i pornografii - Nowicki 2013: 157). On the margins of description of some forgotten, province museum in Central Europe, he gives a large critique of the Western institution of famous galleries like the Louvre (called by him "bombastic Ford Nox of art with marble and canvas instead of gold"; bombastyczny Luwr, ten Fort Nox sztuki z marmurem i płótnem zamiast złota-158). Therefore he repeats, although in a highly radical form, one of the stereotypes of Polish travel essays on Italy. Nowicki depicts the contemporary, grotesque religion of art with irony:

\begin{abstract}
Muzeum staje się miejscem obowiązku, opresji, tu trzeba dygać grzecznie przed płótnami wymalowanymi na hektary, przed podpisami, przed nazwiskami. A te małe zakurzone zbiory na obrzeżach świata, w rzadko odwiedzanych muzeach są mnie wymuskane, pokazują rzeczy gdzie indziej już nieoglądane, kolekcję krawatów, okulary i syjamskie bliźnięta. Są esencją kraju, który je wydał, ledwie wydobywającego się z błota. (Nowicki 2013: 158)
\end{abstract}

The museum has become a place of duty and oppression. One has to curtsy politely in front of kilometres of painted canvas, in front of signatures, in front of names. While those little dusty gatherings at the margins of the world, housed in rarely visited museums are less smoothed but they show things that could not be seen anywhere else yet: a collection of ties, glasses and Siamese twins. They are an essence of a country that bore them, hardly peeking from mud. [translation by the author of the article]

An unusual collection of this type occupies also Nowicki's "imaginary museum" which, as an effect, starts to resemble a cabinet of curiosities. With no doubts are such "dusty gatherings" of objects recognized by this author as par excellence auratic - bound with particular place and historical moment.

Despite his above-quoted denigration of the commonly favoured expositions of masterpieces, in two noticeable excerpts the author of Salki surprisingly presents a testimonial of an auratic experience of paintings by George de La Tour. The first fragment is about admiring The Cheat with the Ace of Diamonds, (nota bene this painting is housed in the Louvre) and contains an ekphrasis filled with enthusiasm ("the one of those unbelievably deliberately projected explosions of painter's virtuosity, the profusion of colours [...]" stanąem przed [...] jednym $z$ tych nieprawdopodobnie przemyślanych rozbłysków malarskiej wirtuozerii, tej feerii kolorów - 162). This description could be easily 
ascribed to the already analysed essay writing created by the effective defenders of values of European art and culture, like, for instance, Herbert or Karpiński. But in Salki this affirmative reception of a picture is immediately confronted with an earlier and evidently different experience of another La Tour's painting - housed in the State Art Gallery in Lviv:

Na obraz La Toura natknąłem się niespodziewanie i właściwie nie był to obraz, ale czarny prostokąt, spękany i wybrzuszony, ledwie wtedy czytelny. Nie potrafiłem odejść. Nokturn La Toura był pokryty dodatkową patyna, oprócz historii malarza i mojej z nim przygody nakładała się nań historia malatury. Wiele przeszła, raz za razem poddawana różnorakim torturom, aż wzdęła się i załamała pod sczerniałym werniksem, gotowa odpaść. Doczytywałem się obrazu pod tą maskującą siatka, przypatrywałem chaosowi spojrzeń, które wzajem do siebie prowadzą i zdradzają nie tylko gwałtowny charakter tego malarstwa, ale też - po raz kolejny - jego przemyślaną strukturę. La Tour z Lwowskiej Galerii Sztuki doskonale oddaje historię miasta, które przechowuje to płótno: w sali pomalowanej na brudnozielono, z zaciekami wody, w kącie wisiało dzieło niewątpliwie warte podróży. (...) Nawet tutejsze muzea były jeszcze jak dotknięte gangreną, opryskliwe i wzbudzające strach. (Nowicki 2013: 163)

I unexpectedly came up against La Tour's picture and it wasn't exactly a picture but a black rectangle, chapped and bellied, hardly readable. I couldn't leave. Nocturne by de La Tour was covered with an additional patina, alongside the history of the painter and my adventure with him there was a coating of history of painted overlay. It had experienced a lot, from time to time it had been tortured till it became inflated and broke under the blackened varnish, ready to fall down. I tried to read an image under this camouflage net, I looked at the chaos of glances that led one to another and revealed not only the violent character of this art but also - again - its purposefully considered structure. La Tour at Lviv gallery perfectly presented the history of city that kept the canvas: in the corner of a dirty green room, with some damp patches, there was a work undoubtedly worth travelling to. [...] Even local museums were still like affected with gangrene, harsh and terrifying. [translation by the author of the article]

Undoubtedly, this work presents itself as full of aura but the most important fact is that this desired quality is grounded due to the damage of the picture (at the same time it sounds similar to Iwaszkiewicz's complaints on excessive renovation of old works as a practice that annihilates aura). Nowicki wrote in an analogues way about his experience of Antonello da Messina's Crucifixion housed in Brukenthal Museum in Sibiu: "the version from Brukenthal is full of cracks and bellied, and that is why it is touching, as a testimony of the fate of this city, this country, all those countries, as an accidently created map of damages" (ta wersja od Brukhentala jest petna spękan i wybrzuszeń $i$ właśnie przez to poruszająca, jako świadectwo losów tego miasta, 
tego kraju, tych wszystkich krajów, jako przypadkowo powstała mapa zniszczeń -161-162). The aura is developed here not due to a picture staying in the original location where it was created, but due to its in-separable relation with the history of the city where the painting was housed for years. All the events that the painting was exposed to, left their traces in its ruined materiality which brings the uniqueness of the object marked by history.

What is essential for my analysis, is that when Nowicki in his collection of essays entitled Dno oka writes about the aura of old, damaged photographs, he presents the identical approach. As he claims, in case of fractured prints or abortive images "the aura is created by time that has passed since their creation because it has damaged and torn the paper, which means it has weaved them with insinuation. [...] For all those photographs, primarily those unworthy anyone's attention, the entropy is a salvation, a spring into the cosmos of images which are singled out from garbage by the hand of a curator (a collector, an author of a text) and placed on the pedestal" (aurę tworzy czas, jaki uptynat od ich wykonania - bo zniszczyt, podart papier, czyli osnut niedopowiedzeniem. (...) Dla tych pierwotnie niewartych uwagi fotografii entropia jest ratunkiem, skokiem w kosmos obrazów, które ręka kuratora (zbieracza, autora tekstu) wyławia ze śmietnika i wystawia na piedestat - Nowicki 2010: 173). The essayist openly declares: "All this writing is caused by one reason only: to stand aside those real, and therefore harsh, pictures" (Całe to pisanie po to właśnie: żeby stanać po stronie obrazów rzeczywistych, więc chropawych -177). He discredits smooth copies or virtual images which are separated from the past and drift without any chance for another rooting. Nowicki's attitude towards old photographs entails an approval of their inevitable fading, and of their disintegration in the end. Moreover, it also means permission for forgetting about pictured persons and places, for their alleged nonexistence. It is worth noticing that, although Benjamin, who created the notion of aura, is famous for disfavouring photographs as serial, undistinctive reproductions, he underlined auratic appearance of the earliest, long-exposed portraits.

When contemporary Polish essays on paintings and those on photographs are considered together as a specific kind of discourse, their association could be regarded in the context of historical metamorphoses. I tried to show that in case of famous, aged masterpieces an essayist seeking an auratic experience of images meets numerous obstacles (crowds of tourists in galleries, the overwhelming repertoire of other authors' interpretations). As a consequence of this situation, the essays on old photographs could be interpreted as a serious alternative: a kind of asylum for an experience of aura in the field of visual objects. Nowicki's writings and the 
essayistic ekphrases by Jacek Dehnel, gathered in an artful volume Fotoplastikon, might be treated as a literary proof of this daring hypothesis.

The strategy of collecting images in order to build a private "imaginary museum", so characteristic for essayists interested in paintings, could be easily detected in texts on photographs. Nowicki and Dehnel often recall a story about circumstances of acquiring particular chosen prints: about visiting flea markets, antique shops or about internet auctions. Objects in their collections, according to Nowicki's words, are "singled out from garbage". In the travel essays on paintings there is a counterpart of this narration about discovering adorable pictures, while Herbert, Karpiński, Bieńkowska or Iwaszkiewicz also tend to describe exhaustively the road they had to take to experience a view of a certain masterpiece. In both types of essays, on the margins of accounts of discovering a fascinating picture, there is often a reflection on the role of chance and destiny, on mysterious entanglement of factors which led to noticing an outstanding image.

Dehnel and Nowicki perform a kind of a time travel, because they are interested mostly in the photographs dating from circa 1880 to 1950 . However, when a private collection is meant to be build the adequate age of a print is not the only one decisive factor. What counts the most is a poignant detail causing the specific anxiety of sensitive viewer (the Roland Barthes' term punctum is often used to describe this feeling). Again it results in a search of singular experience and for an exciting novelty or otherness. In practice the pursuit of aura repeatedly turns out to be a tendency of selecting phenomena that differ from today's sensibility and sometimes seem to be a bit strange (just like in Nowicki's and Stasiuk's travel essays). In Fotoplastikon the catalogue of those provocative motives is very ample and it could be alleged with aesthetics of "camp" (Sontag 1966). The writer concentrates on the mentality of belle époque and the times of two world wars and selects photographs attitudinized, made for the shows, in costumes. Jacek Dehnel as a "colonial connoisseur" (Zalewski 2010: 263) tests various borders of otherness: picks up pictures of deformed bodies, trails the race differences or sexual differences and acts of discrimination. He wants to know the story of persons from a photo and thanks to the work of imagination and free speculations he often brings chosen pictures "back to life".

Summing the above inquiry up, the evident anachronous impulse and imaginary time travelling commenced due to a certain visual stimulus, as the tendency that let me to draw a parallel between travel essays on historical paintings and essays on old photographs, encircles a large area of potential models of experiencing images and some of these models do not have many features in common with a simple admiration of a master- 
piece. The project of searching for auratic experience sometimes means transgressing the kind of perception related to alleged beauty or perfection of a picture (however it does not exclude such an approach). Other interesting outlooks come into play, also as far as the contact with painting is concerned, for example: fascination with otherness, strangeness, horror. A certain historical sense seems to be a key element of all the presented essays, but it is different from the attitude that resulted in establishing the institution of museum. It is a very selective historical sense: a singular voice of an essayist.

\section{Bibliography}

Adorno Theodor W. 1984, "The Essay as Form”, trans. B. Hullet-Kentor, F. Will, New German Critique, No. 30 (Spring - Summer).

Atkins G. Douglas 2005, Tracing the Essay. Through Experience to Truth, Athens and London: The University of Georgia Press.

Barthes Roland 1981, Camera Lucida: Reflections on Photography, trans. R. Howard, New York: Hill and Wang.

Benjamin Walter 1968, The Work of Art in the Age of Mechanical Reproduction, [in:] Illuminations, ed. H. Arendt, London: Fontana.

Benjamin Walter 1999, Little History of Photography, trans. E. Jephcott and K. Shorter, [in:] Walter Benjamin: Selected Writings, ed. M. Bullock and M. W. Jennings, vol. 2, part 2, 1931 - 1934, Cambridge: The Belknap Press of Harvard University Press.

Bense Max 2012, [From On the Essay and Its Prose], trans. E. Sampson, [in:] Essayists on the Essay, ed. C.H. Claus, N. Stuckey-French, Iowa City: University of Iowa Press.

Bieńkowska Ewa 2002, Co mówia kamienie Wenecji, Gdansk: słowo / obraz terytoria.

Dehnel Jacek 2009, Fotoplastikon, Wydawnictwo WAB, Warsaw.

Obaldia Claire de 1995, Essayistic Spirit. Literature, Modern Criticism and the Essay, Oxford: Laredon Press.

Essayists on the Essay 2012, ed. C.H. Claus, N. Stuckey-French, Iowa City: University of Iowa Press.

Herbert Zbigniew 1985, Barbarian in the Garden, trans. M. March and J. Anders, Manchester: Carcanet.

Hollander John 1988, “The Poetics of Ekphrasis”, Word \& Image, No. 4.

Iwaszkiewicz Jarosław 2008, Podróże do Włoch, Warsaw: Państwowy Instytut Wydawniczy. Karpiński Wojciech 2013, Twarze, Warsaw: Fundacja Zeszytów Literackich.

Karpiński Wojciech 2008, Pamięć Włoch, Warsaw: Fundacja Zeszytów Literackich.

Klaus Carl H. 2012, Toward a Collective Poetics of Essay, [in:] Essayists on the Essay, ed. C.H. Claus, N. Stuckey-French, Iowa City: University of Iowa Press. 
Lopate Phillip 1994, Introduction, [in:] The Art of the Personal Essay, ed. Ph. Lopate, New York: Anchor-Doubleday.

Lopate Phillip 2012, What Happened to the Personal Essay?, [in:] Essayists on the Essay, ed. C.H. Claus, N. Stuckey-French, Iowa City: University of Iowa Press.

Malraux Andre 1967, Museum Without Walls, trans. S. Gilbert, F. Price, New York: Doubleday.

Nowicki Wojciech 2010, Dno oka. Eseje o fotografii, Wołowiec: Wydawnictwo Czarne.

Nowicki Wojciech 2013, Salki, Wołowiec: Wydawnictwo Czarne.

Pater Walter 2012, [From Dialectic], [in:] Essayists on the Essay, ed. C.H. Claus, N. StuckeyFrench, Iowa City: University of Iowa Press.

Sanders Scott Russel 2012, [From Singular First Person], [in:] Essayists on the Essay, ed. C.H. Claus, N. Stuckey-French, Iowa City: University of Iowa Press.

Sendyka Roma 2006, Nowoczesny esej. Studium historycznej świadomości gatunku, Cracow: TAiWPN Universitas.

Sendyka Roma 2009, „Esej i ekfraza (Herbert - Bieńkowska - Bieńczyk) „, Przestrzenie Teorii, No.11.

Shallcross Bożena 2002, Through the Poet's Eye. The Travels of Zagajewski, Herbert and Brodsky, Evanston: Northwestern University Press.

Sontag Susan 1966, Against Interpretation and Other Essays, New York: Straus \& Giroux.

Stasiuk Andrzej 2004, Jadac do Babadag, Wołowiec: Wydawnictwo Czarne.

Stasiuk Andrzej 2011, Dziennik pisany później, Wołowiec: Wydawnictwo Czarne.

Szalewska Katarzyna 2012, Pasaż tekstowy. Czytanie miasta jako forma doświadczania przeszłości we wspótczesnym eseju polskim, Cracow: TAiWPN Universitas.

Szczuciński Adam 2008, Włoskie miniatury, Warsaw: Fundacja Zeszytów Literackich.

Zagańczyk Marek 2005, Droga do Sieny, Warsaw: Fundacja Zeszytów Literackich.

Zalewski Cezary 2010, Pragnienie, poznanie, przemijanie. Fotograficzne reprezentacje w literaturze polskiej, Cracow: TAiWPN Universitas. 